\title{
Is neuroendocrine differentiation a prognostic factor in poorly differentiated colorectal cancer?
}

\author{
Yue Chen, Fang Liu*, Qingkai Meng and Siping Ma
}

\begin{abstract}
Background: To determine the prognostic relevance of neuroendocrine differentiation in poorly differentiated colorectal cancer.

Methods: The clinicopathological features and survival of 70 patients with poorly differentiated colorectal cancer were analyzed retrospectively. Chromogranin A and synaptophysin were used as neuroendocrine markers. Patients were followed-up for more than 3 years or until death.

Results: Of these 70 patients, 36 showed neuroendocrine differentiation. In univariate prognostic analysis, the patients with lymph node metastasis $(P<0.001)$, advanced TNM stage $(P<0.001)$, and neuroendocrine differentiation $(P=0.003)$ tended to have a poor prognosis. However, only lymph node metastasis was associated with a poor prognosis in multivariate analysis $(P<0.001)$. Patients with neuroendocrine differentiation were associated with lymph node metastasis $(P=0.006)$.

Conclusions: Neuroendocrine differentiation in poorly differentiated colorectal cancer was not a direct prognostic factor in these patients. Lymph node metastasis was a direct prognostic factor in these patients. Patients with neuroendocrine differentiation were associated with lymph node metastasis.
\end{abstract}

Keywords: Poorly differentiated colorectal cancer, Neuroendocrine differentiation, Lymph node metastasis, Prognosis

\section{Background}

Neuroendocrine differentiation (NED) has been observed in cancers of several non-neuroendocrine organs, including the gastrointestinal tract. Many studies have evaluated the clinical prognostic value of NED in colorectal cancer $(\mathrm{CRC})$. However, conflicting data exist in these studies. In the study by Mori et al. [1], NED did not influence patient prognosis. Similarly, Lloyd et al. [2] showed that, in 289 patients, NED did not influence prognosis in moderately differentiated colorectal carcinomas. In contrast, in recent years, studies have revealed that NED does influence patient prognosis. Bernick et al. [3] studied 38 CRC patients with NED and found that the prognosis of these patients was poor. Similar findings were reported in a meta-analysis by Zeng et al. [4]. Intriguingly, some

\footnotetext{
* Correspondence: liufang666555@sina.com

Department of colorectal surgery, Cancer Hospital of China Medical University, Liaoning Cancer Hospital \& Institute, No. 44 Xiaoheyan Road, Dadong District, Shenyang 110042, Liaoning Province, People's Republic of China
}

(c) The Author(s). 2017 Open Access This article is distributed under the terms of the Creative Commons Attribution 4.0 International License (http://creativecommons.org/licenses/by/4.0/), which permits unrestricted use, distribution, and reproduction in any medium, provided you give appropriate credit to the original author(s) and the source, provide a link to the Creative Commons license, and indicate if changes were made. The Creative Commons Public Domain Dedication waiver (http://creativecommons.org/publicdomain/zero/1.0/) applies to the data made available in this article, unless otherwise stated. studies have indicated that CRC with NED was correlated with liver metastasis and advanced tumor stages $[3,5]$.

Poorly differentiated colorectal cancer (PDCRC) comprises 5 to $25 \%$ of all CRCs [6-9]. It is known that PDCRC is usually associated with a poor prognosis. NED is often found in PDCRC [5]. The prognosis of PDCRC with NED is currently still unclear. Here, we preliminarily studied whether NED was a prognostic factor in patients with PDCRC.
Methods
Patients
Between 2008 and 2012, 70 patients with primary PDCRC who underwent radical resection were analyzed retrospectively. All patients with TNM II and III tumors, according to the 7th edition of the American Joint Committee on Cancer/Union International control Cancer (AJCC/UICC) tumor-node-metastasis (TNM) staging system, received adjuvant therapy after surgery. 
Histology specimens were evaluated by two senior pathologists, and the diagnosis of PDCRC was confirmed in all patients. Patients who died perioperatively and those with distant organ metastasis or secondary malignancy were excluded.

\section{Immunohistochemistry}

Hematoxylin and eosin-stained specimens from each patient were available for review. In addition, each specimen was analyzed for the biological markers of NED, synaptophysin (Syn), and chromogranin A (CgA) by immunohistochemistry. The number of Syn or CgA immunoreactive cells was determined using an eyepiece at highpower field (HPF). Immunoreactive cells were counted in at least ten most concentrated areas of tumor cells, and the results were presented as the mean number of immunoreactive cells per HPF. When no immunoreactive tumor cells for CgA and Syn were noted in all tumor fields, the tumor was classified as $\operatorname{NED}(-)$. Moreover, when $\geq 1$ tumor cells/HPF were positive for CgA and/or Syn, the tumor was classified as $\mathrm{NED}(+)$ [10-12]. Furthermore, $\mathrm{NED}(+)$ tumors were assigned to three subgroups based on the presence of immunoreactive cells per HPF: subgroup 1(SG1) had less than 10\% immunoreactive cells of the total number of cells per HPF; subgroup 2(SG2) had $10-20 \%$ immunoreactive cells; subgroup 3(SG3) had more than $20 \%$ immunoreactive cells. According to the 2010 World Health Organization (WHO) classification, specimens with more than $30 \%$ immunoreactive cells were classified as mixed adenoneuroendocrine carcinoma (MANEC), and these patients were excluded from the study.

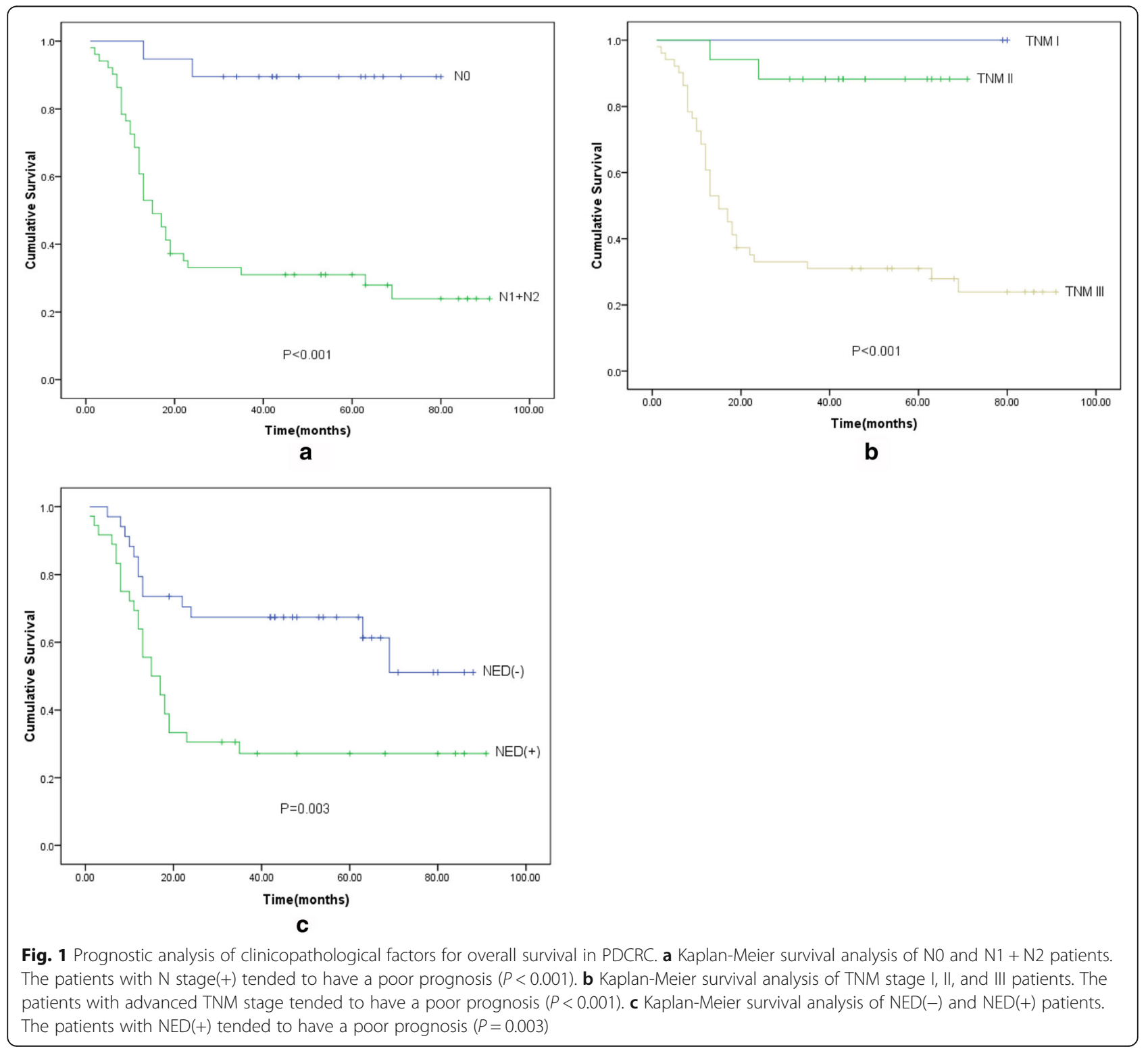




\section{Statistics}

All statistical analyses were performed using SPSS (version 16.0). Pearson's chi-squared test was used to investigate correlations of clinicopathological features between the $\mathrm{NED}(+)$ and $\mathrm{NED}(-)$ groups. Multivariate analysis was performed using logistic regression. Overall survival was assessed by the Kaplan-Meier method. Statistical significance between the survival curves of clinicopathological features was calculated by the log rank test. Significant variables were then examined by multivariate analysis using the Cox model. $P$ values $<0.05$ were considered statistically significant.

\section{Results}

\section{General information}

Seventy patients (36 males and 34 females) were diagnosed with PDCRC, including 36 (51.4\%) NED(+) patients and $34(48.6 \%) \mathrm{NED}(-)$ patients. The mean age was 60.2 years (range: $36-86$ years). Of these patients, 2 had stage I cancer, 17 had stage II, and 51 had stage III, which included 45 cases of colon cancer and 25 cases of rectal cancer. The median survival time of these patients was
47.656 months. Thirty-nine of 70 patients died during the follow-up period.

\section{Prognostic factors of PDCRC}

Survival analyses were based on 70 patients with complete follow-up data. Overall mean survival time was 47.656 months (95\% confidence interval: $38.557-56.755$ ) and 3-year overall survival (3-year OS) was $0.469 \pm$ 0.060 .

In these PDCRC cases, the patients with $\mathrm{N}$ stage $(+)$ $(P<0.001)$, advanced TNM stage $(P<0.001)$, and NED $(+)$ $(P=0.003)$ tended to have a poor prognosis(Fig. 1). However, there was no significant difference in 3-year OS in terms of age, gender, tumor location, lymph nodes retrieved, and $\mathrm{T}$ stage (Table 1 ).

In multivariate analysis using the Cox model, only lymph node metastasis (LNM) was associated with a poor prognosis $(P<0.001)$ (Table 1$)$.

Moreover, by stratification analysis based on the degree of NED, we analyzed the prognosis of SGs1, 2, and 3. Interestingly, with the increasing presence of immunoreactive cells, the subgroup with higher expression tended

Table 1 Prognostic analysis of clinicopathological factors for overall survival in poor differentiated colorectal cancer patients

\begin{tabular}{|c|c|c|c|c|c|}
\hline \multirow[t]{2}{*}{ Clinicopathological factors } & \multicolumn{3}{|c|}{ Univariate analysis } & \multicolumn{2}{|c|}{ Multivariate analysis } \\
\hline & Number(\%) & 3-year OS & $P$ value & $P$ value & $\mathrm{RR}$ \\
\hline Age & & & 0.330 & & \\
\hline$<65$ years & $43(61.4 \%)$ & $0.510 \pm 0.077$ & & & \\
\hline$\geq 65$ years & $27(38.6 \%)$ & $0.407 \pm 0.095$ & & & \\
\hline Gender & & & 0.582 & & \\
\hline Male & $36(51.4 \%)$ & $0.408 \pm 0.083$ & & & \\
\hline Female & $34(48.6 \%)$ & $0.529 \pm 0.086$ & & & \\
\hline Tumor location & & & 0.092 & & \\
\hline Colon & $45(64.3 \%)$ & $0.503 \pm 0.083$ & & & \\
\hline Rectum & $25(35.7 \%)$ & $0.315 \pm 0.094$ & & & \\
\hline T stage & & & 0.373 & & \\
\hline $\mathrm{T} 1+\mathrm{T} 2$ & $5(7.1 \%)$ & $0.600 \pm 0.219$ & & & \\
\hline $\mathrm{T} 3+\mathrm{T} 4$ & $65(92.9 \%)$ & $0.459 \pm 0.062$ & & & \\
\hline N stage & & & $<0.001^{*}$ & $<0.001^{*}$ & 3.028 \\
\hline No & 19(27.1\%) & $0.895 \pm 0.070$ & & & \\
\hline $\mathrm{N} 1+\mathrm{N} 2$ & $51(72.9 \%)$ & $0.310 \pm 0.065$ & & & \\
\hline TNM stage & & & $<0.001^{*}$ & 0.384 & \\
\hline । & $2(2.9 \%)$ & $N A^{a}$ & & & \\
\hline$\|$ & $17(24.3 \%)$ & $0.882 \pm 0.078$ & & & \\
\hline III & $51(72.8 \%)$ & $0.310 \pm 0.065$ & & & \\
\hline NED & & & $0.003^{*}$ & 0.111 & \\
\hline+ & $36(51.4 \%)$ & $0.272 \pm 0.075$ & & & \\
\hline- & $34(48.6 \%)$ & $0.674 \pm 0.081$ & & & \\
\hline
\end{tabular}

*Indicated statistical significance $(P<0.05)$

${ }^{\mathrm{a}}$ Not applicable 


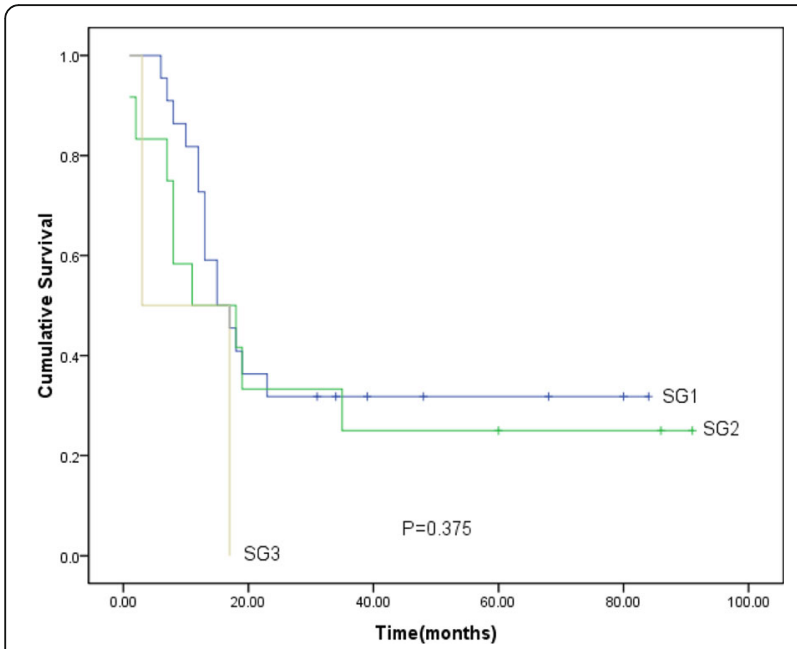

Fig. 2 Prognostic analysis of SGs 1, 2, and 3 for overall survival in $\mathrm{NED}(+)$ patients. There were no significant differences among three subgroups $(P=0.375)$ to have a poor prognosis. However, this trend did not reach statistical significance (Fig. 2).

\section{Clinicopathological features and neuroendocrine differentiation}

Univariate analysis revealed that $\mathrm{N}$ stage $(P=0.010)$ and TNM stage $(P=0.018)$ had correlation with NED. Furthermore, in multivariate analysis, only $\mathrm{N}$ stage was associated with NED $(P=0.006)$. There was no significant association between NED and age, gender, tumor location, lymph nodes retrieved, and T stage (Table 2).

\section{Discussion}

In a previous study, the incidence of NED in PDCRC was $41.5 \%$ [12]. In our study, the incidence was $51.4 \%$, which was close to that in Liu's study. Since NED is quite common in PDCRC, it is important to study the influence of NED in PDCRC patients.

There is controversy regarding the prognostic significance of NED in CRC [1-4, 13-15]. In our study, there were statistically significant differences in 3-year OS in terms of $\mathrm{N}$ stage, TNM stage, and NED in patients with

Table 2 Correlation between clinicopathological factors and neuroendocrine differentiation

\begin{tabular}{|c|c|c|c|c|c|c|}
\hline \multirow{2}{*}{$\begin{array}{l}\text { Clinicopathological } \\
\text { factors }\end{array}$} & \multirow[t]{2}{*}{ Number(\%) } & \multicolumn{2}{|l|}{ NED } & \multirow[t]{2}{*}{ Univariate analysis } & \multicolumn{2}{|c|}{ Multivariate analysis } \\
\hline & & $+(\mathrm{SG} 1, \mathrm{SG} 2, \mathrm{SG} 3)$ & - & & $\overline{P \text { value }}$ & OR \\
\hline Age & & & & 0.955 & & \\
\hline$<65$ years & $43(61.4 \%)$ & $22(15,6,1)$ & 21 & & & \\
\hline$\geq 65$ years & $27(38.6 \%)$ & $14(7,6,1)$ & 13 & & & \\
\hline Gender & & & & 0.816 & & \\
\hline Male & $36(51.4 \%)$ & $19(14,4,1)$ & 17 & & & \\
\hline Female & $34(48.6 \%)$ & $17(8,8,1)$ & 17 & & & \\
\hline Tumor location & & & & 0.943 & & \\
\hline Colon & $45(64.3 \%)$ & $23(13,9,1)$ & 22 & & & \\
\hline Rectum & $25(35.7 \%)$ & $13(9,3,1)$ & 12 & & & \\
\hline Lymph nodes retrieved & & & & 0.492 & & \\
\hline$<12$ & $18(25.7 \%)$ & $8(6,1,1)$ & 10 & & & \\
\hline$\geq 12$ & $52(74.3 \%)$ & $28(16,11,1)$ & 24 & & & \\
\hline T stage & & & & $0.669^{a}$ & & \\
\hline $\mathrm{T} 1+\mathrm{T} 2$ & $5(7.1 \%)$ & $2(2,0,0)$ & 3 & & & \\
\hline $\mathrm{T} 3+\mathrm{T} 4$ & $65(92.9 \%)$ & $34(20,12,2)$ & 31 & & & \\
\hline $\mathrm{N}$ stage & & & & $0.010^{*}$ & $0.006^{*}$ & 2.391 \\
\hline NO & $19(27.1 \%)$ & $5(5,0,0)$ & 14 & & & \\
\hline $\mathrm{N} 1+\mathrm{N} 2$ & $51(72.9 \%)$ & $31(17,12,2)$ & 20 & & & \\
\hline TNM stage & & & & $0.018^{\mathrm{b}, *}$ & 0.755 & \\
\hline 1 & $2(2.9 \%)$ & $0(0,0,0)$ & 2 & & & \\
\hline$\|$ & $17(24.3 \%)$ & $5(5,0,0)$ & 12 & & & \\
\hline III & $51(72.8 \%)$ & $31(17,12,2)$ & 20 & & & \\
\hline
\end{tabular}

${ }^{\mathrm{a}}$ Fisher's exact test

bikelihood radio

*Indicated statistical significance $(P<0.05)$ 
PDCRC. Multivariate analysis indicated that $\mathrm{N}$ stage $(+)$ was a significant negative prognostic factor for 3-year OS, which was not surprising as this parameter is a wellknown marker with prognostic relevance [16-19]. In a previous study, de Bruine et al. [14] suggested that adenocarcinomas with NED tended to exhibit early LNM, which was similar to the results in our correlation analysis. We found that patients with NED were associated with LNM. Therefore, it may be deduced that NED, which might influent LNM, affected the prognosis of patients with PDCRC, rather than being a direct prognostic factor in these patients. In many studies, there were differences in the proportion of patients with LNM due to small sample sizes $[1-4,13-15]$. Therefore, this may be the reason why there is controversy regarding the prognostic significance of NED in CRC. Moreover, the biological mechanisms underlying PDCRC with NED and metastasis remain unclear. It is known that neuroendocrine differentiated cells secrete neurohormonal substances by the autocrine or paracrine loop. In a previous study, biogenic amines and polypeptide hormones played a role in the growth regulation of normal and neoplastic intestinal epithelia [20]. Hypothetically, NED could stimulate growth and metastatic capacity through the secretion of neurohormonal substances.

Moreover, by further stratified analysis, we found that prognoses of three subgroups did not reach statistical significance. But, the subgroup with higher expression tended to have a poor prognosis. This might be due to small sample size in our study. Therefore, further investigations are required to confirm this hypothesis.

TNM staging is a classic staging method used to predict survival. However, with the development of molecular medicine, TNM staging may be less reliable in predicting survival, as shown in the research by Eschrich et al. They argued that molecular staging might provide an accurate prognosis for cancer patients [21]. Our data indicated that patients with NED were associated with LNM. Therefore, NED may be an important factor in molecular staging. Several studies had indicated that the neuroendocrine phenotype was associated with increased chemosensitivity in lung cancer [22, 23] and in colorectal cell lines [24]. Therefore, NED might also be helpful in the therapy of CRC. Further investigations are required in this area.

\section{Conclusions}

NED is a common event in PDCRC. NED in PDCRC is not a direct prognostic factor in these patients. LNM is a direct prognostic factor in these patients. Patients with NED were associated with LNM. Moreover, NED, which might influent LNM, affected the prognosis of patients with PDCRC. Further research on this important issue is required.

\section{Abbreviations}

3-year OS: 3-year overall survival; AJCC/UICC: American Joint Committee on Cancer/ Union for International Cancer Control; CgA: Chromogranin A; CRC: Colorectal cancer; HPF: High-power field; LNM: Lymph node metastasis; MANEC: Mixed adenoneuroendocrine carcinoma; NED: Neuroendocrine differentiation; PDCRC: Poorly differentiated colorectal cancer; SG1: Subgroup 1; SG2: Subgroup 2; SG3: Subgroup 3; Syn: Synaptophysin; TNM: Tumor-nodemetastasis; WHO: World Health Organization

\section{Acknowledgments \\ We would like to thank Dr Yongxi Song, at First Hospital of China Medical University, for critical revision.}

\section{Funding}

This work was supported by the Natural Science Foundation of Liaoning Province (no: 2016003002).

\section{Availability of data and materials}

The datasets used and/or analyzed during the current study are available from the corresponding author on reasonable request.

\section{Authors' contributions}

YC made the statistics analysis and wrote the paper. FL managed the design, performed the operation, and modified the paper. QM performed the follow-up and collected the clinicopathological features of the patients. SM performed the correlation of clinicopathological factors and assisted with the survival analysis. All authors read and approved the final manuscript.

\section{Competing interests}

The authors declare that they have no competing interests.

\section{Consent for publication}

Not applicable.

\section{Ethics approval and consent to participate}

This study was approved by the Ethics Committee for Clinical Research of Liaoning Cancer Hospital \& Institute.

\section{Publisher's Note}

Springer Nature remains neutral with regard to jurisdictional claims in published maps and institutional affiliations.

Received: 15 November 2016 Accepted: 23 March 2017

Published online: 28 March 2017

\section{References}

1. Mori M, Mimori K, Kamakura T, Adachi Y, Ikeda Y, Sugimachi K. Chromogranin positive cells in colorectal carcinoma and transitional mucosa. J Clin Pathol. 1995;48:754-8.

2. Lloyd RV, Schroeder G, Bauman MD, Krook JE, Jin L, Goldberg RM, et al. Prevalence and prognostic significance of neuroendocrine differentiation in colorectal carcinomas. Endocr Pathol. 1998;9:35-42.

3. Bernick PE, Klimstra DS, Shia J, Minsky B, Saltz L, Shi W, et al. Neuroendocrine carcinomas of the colon and rectum. Dis Colon Rectum. 2004;47:163-9.

4. Zeng YJ, Lai W, Liu L, Wu H, Luo XX, Wang J, et al. Prognostic significance of neuroendocrine differentiation in colorectal adenocarcinoma after radical operation: a meta-analysis. J Gastrointest Surg. 2014;18:968-76.

5. Shinji S, Naito Z, Ishiwata T, Tanaka N, Furukawa K, Suzuki H, et al. Neuroendocrine cell differentiation of poorly differentiated colorectal adenocarcinoma correlates with liver metastasis. Int J Oncol. 2006;29:357-64.

6. Taniyama K, Suzuki H, Matsumoto M, Hakamada K, Toyama K, Tahara E. Flow cytometric DNA analysis of poorly differentiated adenocarcinoma of the colorectum. Jpn J Clin Oncol. 1991;21:406-11.

7. Cass AW, Million RR, Pfaff WW. Patterns of recurrence following surgery alone for adenocarcinoma of the colon and rectum. Cancer. 1976;37:2861-5.

8. Copeland EM, Miller LD, Jones RS. Prognostic factors in carcinoma of the colon and rectum. Am J Surg. 1968;116:875-81.

9. Chung CK, Zaino RJ, Stryker JA. Colorectal carcinoma: evaluation of histologic grade and factors influencing prognosis. J Surg Oncol. 1982;21:143-8. 
10. Grabowski P, Schonfelder J, Ahnert-Hilger G, Foss HD, Heine B, Schindler I, et al. Expression of neuroendocrine markers: a signature of human undifferentiated carcinoma of the colon and rectum. Virchows Arch. 2002:441:256-63.

11. Wiedenmann B, Franke WW, Kuhn C, Moll R, Gould VE. Synaptophysin: a marker protein for neuroendocrine cells and neoplasms. Proc Natl Acad Sci U S A. 1986;83:3500-4.

12. Liu $Y, X u J$, Jiao $Y, H u Y, Y i C, L i Q$, et al. Neuroendocrine differentiation is a prognostic factor for stage II poorly differentiated colorectal cancer. Biomed Res Int. 2014; doi:10.1155/2014/789575.

13. Hamada Y, Oishi A, Shoji T, Takada H, Yamamura M, Hioki K, et al. Endocrine cells and prognosis in patients with colorectal carcinoma. Cancer. 1992;69:2641-6.

14. de Bruine AP, Wiggers T, Beek C, Volovics A, von MM, Arends JW, et al. Endocrine cells in colorectal adenocarcinomas: incidence, hormone profile and prognostic relevance. Int J Cancer. 1993;54:765-71.

15. Vortmeyer AO, Lubensky IA, Merino MJ, Wang CY, Pham T, Furth EE, et al. Concordance of genetic alterations in poorly differentiated colorectal neuroendocrine carcinomas and associated adenocarcinomas. J Natl Cancer Inst. 1997:89:1448-53.

16. Kim CH, Huh JW, Kim HR, Kim YJ. Prognostic comparison between number and distribution of lymph node metastases in patients with right-sided colon cancer. Ann Surg Oncol. 2014;21:1361-8.

17. Le VTE, Sigurdson ER, Hanlon AL, Mayer RJ, Macdonald JS, Catalano PJ, et al, Colon cancer survival is associated with increasing number of lymph nodes analyzed: a secondary survey of intergroup trial INT-0089. J Clin Oncol. 2003;21:2912-9.

18. Yasuda K, Adachi Y, Shiraishi N, Yamaguchi K, Hirabayashi Y, Kitano S. Pattern of lymph node micrometastasis and prognosis of patients with colorectal cancer. Ann Surg Oncol. 2001;8:300-4.

19. Gunderson LL, Sargent DJ, Tepper JE, Wolmark N, O'Connell MJ, Begovic M, et al. Impact of $\mathrm{T}$ and $\mathrm{N}$ stage and treatment on survival and relapse in adjuvant rectal cancer: a pooled analysis. J Clin Oncol. 2004;22:1785-96.

20. Johnson LR. Regulation of gastrointestinal mucosal growth. Physiol Rev. 1988;68:456-502

21. Eschrich S, Yang I, Bloom G, Kwong KY, Boulware D, Cantor A, et al. Molecular staging for survival prediction of colorectal cancer patients. J Clin Oncol. 2005; 23:3526-35

22. Graziano SL, Mazid R, Newman N, Tatum A, Oler A, Mortimer JA, et al. The use of neuroendocrine immunoperoxidase markers to predict chemotherapy response in patients with non-small-cell lung cancer. J Clin Oncol. 1989;7:1398-406.

23. Carney DN, Mitchell JB, Kinsella TJ. In vitro radiation and chemotherapy sensitivity of established cell lines of human small cell lung cancer and its large cell morphological variants. Cancer Res. 1983:43:2806-11.

24. Park JG, Oie HK, Sugarbaker PH, Henslee JG, Chen TR, Johnson BE, et al. Characteristics of cell lines established from human colorectal carcinoma. Cancer Res. 1987;47:6710-8.

\section{Submit your next manuscript to BioMed Central and we will help you at every step:}

- We accept pre-submission inquiries

- Our selector tool helps you to find the most relevant journal

- We provide round the clock customer support

- Convenient online submission

- Thorough peer review

- Inclusion in PubMed and all major indexing services

- Maximum visibility for your research

Submit your manuscript at www.biomedcentral.com/submit

) Biomed Central 